\title{
A rheopheresiskezeléssel szerzett első hazai tapasztalatok
}

\author{
Soltész Pál dr. ${ }^{1}$ - Németh Norbert dr. ${ }^{2}$ - Gál Kristóf dr. ${ }^{1}$ \\ Vass Melinda dr. ${ }^{1}$ - Diószegi Ágnes dr. ${ }^{1}$ - ${ }^{\dagger}$ Mechler Ferenc dr. ${ }^{3}$ \\ Fekete Klára dr. ${ }^{3}$ - Somogyi Viktória dr. ${ }^{2}$ - Módis László dr. ${ }^{4}$
}

\author{
${ }^{1}$ Debreceni Egyetem, Általános Orvostudományi Kar, Belgyógyászati Intézet, Angiológiai Nem Önálló Tanszék, \\ valamint Intenzív Osztály és Terápiás Aferezis Részleg (Klinikai Központ), Debrecen \\ ${ }^{2}$ Debreceni Egyetem, Általános Orvostudományi Kar, Sebészeti Mútéttani Tanszék, Debrecen \\ ${ }^{3}$ Debreceni Egyetem, Általános Orvostudományi Kar, Neurológiai Tanszék, Debrecen \\ ${ }^{4}$ Debreceni Egyetem, Általános Orvostudományi Kar, Szemészeti Tanszék, Debrecen
}

\begin{abstract}
Háttér: A rheopheresis egy szelektív, extracorporalis, kettős kaszkádfiltrációs eljárás, mely előzetes plazmaszeparációt követően egy speciális filter segítségével kivonja a vérplazmából a hiperviszkozitásért felelős komponenseket, úgymint alacsony sứrúségű lipoprotein, lipoprotein(a), triglicerid, koleszterin, fibrinogén, a2-makroglobulin, Von Willebrandfaktor, immunglobulin-M.

Módszer és Betegek: Klinikánkon az elmúlt 5 évben MONET filter alkalmazásával összesen 80 kezelést végeztünk hiperviszkozitással összefüggő, időskori száraz maculadegeneratióban, diabeteses alsó végtagi fekélyben, illetve neuropathiában.

Eredmények: A dolgozatban beszámolunk kedvező klinikai tapasztalatainkról, a viszkozitás, a klinikai tünetek és az elektroneurográfiai paraméterek tükrében.

Orv Hetil. 2021; 162(10): 375-382.
\end{abstract}

Kulcsszavak: rheopheresis, terápiás apheresis, magyarországi adatok, új módszerek, időskori száraz maculadegeneratio, diabeteses fekély, diabeteses neuropathia

\section{The first local experiences with rheopheresis treatment}

Background: Rheopheresis is a selective, extracorporeal, double cascade filtration method. After a previous plasma separation, with the help of a special filter it extracts compounds from blood plasma which are responsible for hyperviscosity such as low-density lipoprotein, lipoprotein(a), triglyceride, cholesterine, fibrinogen, a2-macroglobulin, Von Willebrand factor, immunoglobulin M.

Method and Patients: In the past 5 years, with the application of MONET filter we performed 80 therapies to treat age-related macula degeneration, diabetic foot ulcers and neuropathy which are complicated with hyperviscosity.

Results: The review describes our benefical clinical experiences in consideration of viscosity, clinical symptoms and electroneurography parameters.

Keywords: rheopheresis, therapeutic apheresis, national survey in Hungary, new methods, age-related macula degeneration, diabetic foot ulcer, diabetic neuropathy

Soltész P, Németh N, Gál K, Vass M, Diószegi Á, Mechler F, Fekete K, Somogyi V, Módis L. [The first local experiences with rheopheresis treatment]. Orv Hetil. 2021; 162(10): 375-382.

(Beérkezett: 2020. május 5.; elfogadva: 2020. július 24.)

\section{Rövidítések}

AMD $=($ age-related macular degeneration $)$ időskori maculadegeneratio; $\mathrm{ENG}=$ elektroneurográfia; $\mathrm{HDL}=$ (high-density lipoprotein) magas sürüségú lipoprotein; IgM = immunglobulin-M; LDL = (low-density lipoprotein $)$ alacsony sürűségü li- poprotein; MONET $=($ Membrane Filtration Optimised Novel Extracorporeal Treatment) membránfiltrációs optimalizált új extracorporalis kezelés; OCT $=$ (optical coherence tomography) optikaikoherencia-tomográfia; VWF = Von Willebrandfaktor 
A rheopheresiskezelés egy extracorporalis, szelektív, kettős kaszkádfiltrációs eljárás, mely a beteg vér- és plazmaviszkozitását fokozó plazmakomponenseket eltávolítva javítja a páciens mikrocirkulációs statusát. A kezelés két lépcsőben zajlik: ennek során első lépésként szeparációra kerülnek a vér alakos elemei és a vérplazma, majd a második lépésben a vérplazma a kezelésekhez használt rheofilteren áramlik át. A filter képes a 250-300 kDa-nál nagyobb molekulasúlyú plazmaalkotók kiszűrésére, ezáltal eltávolításra kerül az LDL, a lipoprotein(a), a triglicerid, a koleszterin, a fibrinogén, az a2-makroglobulin, a VWF, az IgM. A kezelés további pozitívuma, hogy a protektív HDL nem kerül az eljárás során filtrációra, ahogyan az albumin sem. Az eltávolított plazmakomponensek hatására a kezelés csökkenti a vér- és plazmaviszkozitást [1-3].

A legfrissebb nemzetközi ajánlás (American Society for Apheresis) alapján jelenleg a mikrocirkulációs zavar következtében kialakult időskori száraz maculadegeneratióban első vonalbeli, továbbá sensorineuralis hallásvesztésben szenvedő betegeknek másodvonalbeli terápiaként ajánlott a kezelés [4]. Emellett logikusan kerülhetne alkalmazásra egyéb, hiperviszkozitással járó kórképekben is. Magyarországon korábban ez a kezelési modulus nem került alkalmazásra, a nemzetközi ajánlások azonban szükségessé tették, hogy hazai bevezetése megtörténjen. A Debreceni Egyetem Belgyógyászati Intézetében az Angiológiai Tanszék és a Terápiás Aferezis Részleg együttmúködésében, etikai engedély birtokában, elkezdtük a kezelés alkalmazását időskori száraz maculadegeneratióban, valamint igazolt, hiperviszkozitással összefüggő diabeteses ulcus és/vagy súlyos polyneuropathia eseteiben, továbbá olyan, perifériás artériás érbetegeknél, akiknél az alsó végtagi panaszok és/vagy trophicus zavarok hátterében hiperviszkozitás volt kimutatható.

Az időskorban előforduló látáscsökkenés egyik fö oka napjainkban a maculadegeneratio, amelynek során az éles látásért felelős sárgafolt idegsejtjeinek komplex degeneratív folyamata zajlik. A fejlett országok statisztikái szerint az 50 év felettiek mintegy hatoda szenved ebben a betegségben, továbbá az ezen korosztály esetében kialakult vakságért döntő többségben az időskori maculadegeneratio (AMD) felel [5]. Az AMD jellemzően az idősek betegsége: a megbetegedés elején teljesen tünetmentes, a kórkép előrehaladtával azonban a páciensnek a centrális látása károsodik, így a tünetek közé tartozik az olvasási, közlekedési nehezítettség, az arcok felismerésének zavara [6]. Számos teória született a betegség patofiziológiájával kapcsolatban, oki tényezőként megjelölve az oxidatív stresszt, a mitokondriális diszfunkciót, illetve gyulladásos folyamatokat, hajlamosító tényezőként pedig a mozgásszegény életmódot, a dohányzást [7]. Az viszont bizonyos, hogy a betegség kórlefolyása során nagy mennyiségú intracelluláris lipofuscin, illetve extracelluláris drusen rakódik le, ami a retina atrophiájához és hegesedéséhez vezet. Kulcsfontosságú a progresszióban a retina pigmentepitheliuma alatt elhelyezkedó és azt el- látó capillarishálózat mikrocirkulációs zavara. A rendkívül sürü, magas oxigénkoncentrációt biztosító choriocapillaris-réteg károsodása retinealis pigmentatrophiát és fotoreceptor-pusztulást okoz [8]. A retina-mikrocirkuláció javítása azonban lehetséges rheopheresiskezeléssel [9]. A magas koleszterin-, fibrinogén-, a2-makroglobulin-szint jelentősen növeli a vér viszkozitását, és károsítja a mikrocirkulációt - az AMD-s betegek esetében igazoltan rizikótényezóként jelennek meg az epidemiológiai vizsgálatokban [7].

A diabeteses láb egy olyan súlyos kórkép, amely a diabetes okozta mikrocirkulációs zavar, macroangiopathia és neuropathia következtében kialakuló állapot. A szindróma gyakran vezet az alsó végtag keringési elégtelenségéhez, a páciensek nemritkán szenvednek fekélyektől, súlyos, esetenként türhetetlen alsó végtagi fájdalomtól. Ezen tényezők együttállása circulus vitiosust alkotva nagyon gyakran az alsó végtag amputációjához vezet [10].

A diabeteses polyneuropathia szoros összefüggést mutat a mikrocirkuláció károsodásával. Az idegeket ellátó és azokat behálózó finom érrendszer, a vasa nervorum szükülete és perfúziós zavara az idegsejtek következményes károsodásához vezet. Az idegsejtek anyagcserezavara és ischaemiás károsodása együttesen felelős a diabeteses neuropathia létrejöttéért [11]. Míg kezdetben a páciens jellemzően égő, szúró panaszoktól szenved, addig a késői tünetek esetén a negatív tünetek dominálnak, akár a teljes érzéketlenségig fokozódva, ami kóros talpi nyomáspontok létrehozásával nagymértékben kedvez a fekélyek kialakulásának. A megváltozott tapintásérzés bizonytalanná teszi a páciensek járását, akik az érintett végtagot gyakran túlterhelik, a következményes sérülésekről az érzéketlenség miatt nem vesznek tudomást, így különösen veszélyeztetettek a fekélyek kialakulása szempontjából $[10,12]$.

\section{Betegek és módszerek}

2014 és 2019 között 25 betegen összesen 80 kezelés történt. 18 férfi (átlagéletkoruk 60,7) és 7 nő- (átlagéletkoruk 63,28 ) betegünk volt. 5 páciens időskori száraz maculadegeneratióban szenvedett, ők összesen 25 kezelésben részesültek, továbbá 12 , hiperviszkozitással összefüggő ulcusos páciensen 31 kezelést végeztünk. 6 páciensünknél került diagnosztizálásra diabeteses hiperviszkozitással szövődő neuropathia ulcus nélkül, ezen betegek összesen 22 kezelésben részesültek.

\section{Rheopheresiskezelés}

A kezelés során a páciens két perifériás vénáját kanülálva, Art Universal rendszert (Fresenius Medical Care Kft., Budapest) használva, plazmaszeparációt végeztünk, melyet követően az alakos elemektől elválaszott vérplazmát a MONET filteren keresztüláramoltatva, az alakos elemekkel együtt juttattuk vissza a páciens keringési rend- 
szerébe. Egy kezelés során átlagosan $40 \mathrm{ml} /$ testsúlykilogramm plazma (2500-3300 ml betegenként) került feldolgozásra; antikoagulánsként citrátot alkalmaztunk.

\section{Viszkozitásvizsgálat}

A haemorrheologiai vizsgálat a Sebészeti Mütéttani Tanszéken történt. A betegek vérmintái teljesvér- és plazmaviszkozitásának meghatározása capillaris viszkozimetriai módszerrel történt (Hevimet 40 viszkoziméter; Hemorex Kft., Budapest). A vérviszkozitás meghatározásakor a Mátrai és mtsai által ajánlott matematikai formula segítségével a $40 \%$-os hematokritra korrigált értékek is kiszámításra kerültek [13]. Ezek alapján a teljes vér viszkozitásának felső maximális értéke 4,4 mPas $90 \mathrm{~s}^{-1}$ sebességgradiensnél, míg a plazmaviszkozitás esetében ez 1,4 mPas.

\section{Elektroneurográfiai vizsgálat}

A neuropathia diagnózisa ENG-vel került megállapításra. Az ENG-vizsgálatokat a 9031A006401 Keypoint Clinical System (Natus Medical, Pleasanton, CA, USA) segítségével végeztük. A vizsgálatok a Neurológiai Tanszék Elektrofiziológiai Laboratóriumában történtek, melyek során mindkét alsó végtagon a nervus peroneus motoros válaszait, a nervus peroneus superficialis, a nervus suralis szenzoros válaszait regisztráltuk, továbbá vizsgáltuk a peronealis F-hullám-válaszokat. A vizsgálat során ezen idegek konduktanciája, vezetési latenciája, amplitúdója, illetve vezetési sebessége került meghatározásra. A szenzoros rostok vizsgálata során antidrom irányú, az érzőküszöb másfélszeresével történő ingerlést, míg a motoros rostok esetében szintén antidrom irányú, szupramaximális ingerlést alkalmaztunk. A regisztrált paramétereket hőmérsékletre és korra korrigáltuk. A vizsgálatokat minden esetben klinikai neurofiziológus szakorvos értékelte.

\section{Szemészeti vizsgálat}

A szemészeti vizsgálat során meghatároztuk a legjobban korrigált látóélességet, fundusvizsgálatot végeztünk pupillatágítás után, illetve a folyamat követése céljából optikaikoherencia-tomográfiás (OCT-) felvételeket készítettünk a centrális retina (macula lutea) területéról.

\section{Eredmények}

\section{Idöskori száraz maculadegeneratio igazolt hiperviszkozitással - a rheopheresiskezeléssel szerzett tapasztalataink}

Terápiás Aferezis Részlegünkön 5, száraz maculadegeneratióban szenvedő betegnél alkalmaztunk 25 rheopheresiskezelést. A páciensek átlagéletkora a kezelések meg- kezdésekor 64,4 életév volt. A páciensek jellemző tünetei közé tartozott a homályos látás, a látásélesség csökkenése és a látótérben megjelenő sötét foltok, az általános életminőség nagymértékü romlása. A betegek átlagosan 5 kezelésben részesültek; az 1 betegen alkalmazott legtöbb kezelés 11, míg a legkevesebb rheopheresiskezelés 2 volt.

Elmondható, hogy minden esetben már egyetlen kezelés után, sôt már a kezelés alatt is javult a páciensek szubjektív látásélessége, és az esetek 100\%-ában objektív szemészeti kontrollal is alátámasztható volt a javulás. A páciensek életminőségét nagymértékben javította a rheopheresis, homályos látásuk csökkent, az olvasás, a közlekedés, a mindennapi tevékenységek jelentősen könnyebbé váltak számukra. A szemészeti vizsgálatok során a legjobban korrigált látóélesség minden esetben javult, összességében az 5 beteg 10 szemén 0,2-ről 0,35re nőtt $(\mathrm{p}=0,06)$. A centrális macula vastagsága kezelés előtt 251,4 $\mu \mathrm{m}$ volt, ez a rheopheresis után 245,4 $\mu \mathrm{m}$-re csökkent $(\mathrm{p}=0,09)$.

A haemorrheologiai paraméterek a következőképpen változtak a kezelés hatására: a kiindulási haemorrheologiai paraméterek minden esetben magasak vagy a normálérték felső határán voltak; a páciensek teljesvér-viszkozitásának átlaga 4,92 mPas, míg plazmaviszkozitásuk átlaga 1,65 mPas volt. 2 beteg esetében történt kontrollviszkozitásvizsgálat: 1 . betegünk esetén a teljes vér viszkozitása 6,28 mPas-ról 4,19 mPas-ra csökkent, míg plazmaviszkozitása 1,55 mPas-ról 1,3 mPas-ra csökkent. 2. betegünk teljesvér-viszkozitása a kezelést követően 4,33 mPas-ról 4,22 mPas-ra, míg plazmaviszkozitása 2,69 mPas-ról 1,34 mPas-ra csökkent, s ezáltal a normáltartományba került.

A kezelt 5 betegünk haemorrheologiai paramétereit az 1. táblázatban, az objektív látóélesség és a centrális retinalis vastagság értékének változásait a 2. táblázatban foglaljuk össze.

\section{Diabeteses láb szindrómája igazolt hiperviszkozitással - a rheopheresiskezeléssel szerzett tapasztalataink}

A kezelést olyan betegeken végeztük el, akiknek a macroangiopathiája revascularisatióra alkalmatlan vagy revascularisatióra nem szoruló volt, s microangiopathiás keringési elégtelenségük és/vagy súlyos ENG-vel igazolt polyneuropathiájuk volt kimutatható, teljesvér- és/vagy plazma-hiperviszkozitással.

A betegek közül 12 fekélyes, illetve 10 neuropathiás panaszoktól szenvedett. 4 páciensnél a két kórkép egyszerre állt fenn. A betegek átlagéletkora a kezelések időpontjában 62,2 életév volt. A legtöbb alkalmazott rheopheresis a diabeteses láb szindrómájában 7 , míg a legkevesebb 1 volt; átlagosan 3 kezelésben részesültek a páciensek.

A betegeknél a neuropathia jellemzően égő, szúró, zsibbadó, sokszor türhetetlen alsó végtagi panaszokkal 
1. táblázat |AMD-s páciensek teljesvér- és plazmaviszkozitásának változása a rheopheresiskezelés hatására

\begin{tabular}{|c|c|c|c|c|c|c|c|}
\hline \multirow[b]{2}{*}{ 1. beteg (B. J.) } & \multirow{2}{*}{$\begin{array}{l}\text { Kor } \\
68\end{array}$} & \multirow{2}{*}{$\begin{array}{l}\text { Nem } \\
\text { Férfi }\end{array}$} & \multirow{2}{*}{$\begin{array}{c}\begin{array}{c}\text { A rheopheresisek } \\
\text { száma }\end{array} \\
11\end{array}$} & \multicolumn{2}{|c|}{$\begin{array}{c}\text { Teljesvér-viszkozitás }\left(90 \mathrm{~s}^{-1} \text { sebességgradiensnél) }\right. \\
\text { kezelés elótt és után }[\mathrm{mPas}]\end{array}$} & \multicolumn{2}{|c|}{$\begin{array}{l}\text { Plazmaviszkozitás kezelés előtt } \\
\text { és után [mPas] }\end{array}$} \\
\hline & & & & 6,28 & 4,19 & 1,55 & 1,3 \\
\hline 2. beteg (K. L.) & 54 & Férfi & 5 & 4,33 & 4,22 & 2,69 & 1,34 \\
\hline 3. beteg (K. N.) & 59 & Nő & 2 & 4,38 & - & 1,23 & - \\
\hline 4. beteg (G. F.) & 70 & Nő & 3 & 4,82 & - & 1,43 & - \\
\hline 5. beteg (N. E.) & 71 & Nő & 4 & 4,78 & - & 1,33 & - \\
\hline
\end{tabular}

$\mathrm{AMD}=$ időskori maculadegeneratio

2. táblázat $\mid A M D$-s betegek látásélességének és a centrális retina vastagságának változása a rheopheresiskezelés előtt és után

\begin{tabular}{|c|c|c|c|c|}
\hline \multirow[b]{2}{*}{ 1. beteg (B. J.) } & \multicolumn{2}{|c|}{ A legjobban korrigált látóélesség kezelés előtt és után } & \multicolumn{2}{|c|}{ A centrális retina vastagsága $(\mu \mathrm{m})$ kezelés előtt és után } \\
\hline & $0,08 \mathrm{OD} / 0,1 \mathrm{OS}$ & $0,1 \mathrm{OD} / 0,2 \mathrm{OS}$ & $262 \pm 0,14$ OD $/ 251 \pm 0,11$ OS & $255 \pm 0,2 \mathrm{OD} / 245 \pm 0,15 \mathrm{OS}$ \\
\hline 2. beteg (K. L.) & $0,1 \mathrm{OD} / 0,15 \mathrm{OS}$ & $0,2 \mathrm{OD} / 0,2 \mathrm{OS}$ & $248 \pm 0,13$ OD $/ 252 \pm 0,11$ OS & $243 \pm 0,15$ OD $/ 249 \pm 0,12$ OS \\
\hline 3. beteg (K. N.) & $0,4 \mathrm{OD} / 0,5 \mathrm{OS}$ & $0,5 \mathrm{OD} / 0,7 \mathrm{OS}$ & $241 \pm 0,16$ OD $/ 237 \pm 0,12$ OS & $235 \pm 0,12 \mathrm{OD} / 232 \pm 0,14$ OS \\
\hline 4. beteg (G. F.) & $0,3 \mathrm{OD} / 0,4 \mathrm{OS}$ & $0,5 \mathrm{OD} / 0,5 \mathrm{OS}$ & $245 \pm 0,18 \mathrm{OD} / 249 \pm 0,2 \mathrm{OS}$ & $237 \pm 0,13$ OD $/ 240 \pm 0,14$ OS \\
\hline 5. beteg (N. E.) & $0,1 \mathrm{OD} / 0,15 \mathrm{OS}$ & $0,3 \mathrm{OD} / 0,3 \mathrm{OS}$ & $267 \pm 0,15 \mathrm{OD} / 262 \pm 0,2 \mathrm{OS}$ & $255 \pm 0,14$ OD $/ 256 \pm 0,12$ OS \\
\hline
\end{tabular}

$\mathrm{AMD}=$ időskori maculadegeneratio; $\mathrm{OD}=$ jobb szem; OS = bal szem

3. táblázat | Diabeteses neuropathiában szenvedő páciensek teljesvér- és plazmaviszkozitásának változása a rheopheresis hatására

\begin{tabular}{lccccccc}
\hline & Kor & Nem & $\begin{array}{c}\text { A rheopheresisek } \\
\text { száma }\end{array}$ & $\begin{array}{c}\text { Teljesvér-viszkozitás }\left(90 \mathrm{~s}^{-1} \text { sebességgradiensnél) }\right. \\
\text { kezelés elött és után [mPas }]\end{array}$ & $\begin{array}{c}\text { Plazmaviszkozitás kezelés előtt és után } \\
{[\mathrm{mPas}]}\end{array}$ \\
\hline 6. beteg (G. M.) & 65 & Férfi & 7 & 5,34 & 3,97 & 1,59 & 1,04 \\
\hline 7. beteg (E. J.) & 55 & Férfi & 6 & 4,79 & 4,19 & 2,36 & 1,27 \\
\hline 8. beteg (Cs. Z.) & 62 & Férfi & 2 & 5,56 & 4,46 & 1,36 & 1,19 \\
\hline 9. beteg (M. I.) & 59 & Férfi & 2 & 4,92 & - & 1,34 & - \\
\hline 10. beteg (Cs. L.) & 66 & Férfi & 3 & 6,03 & 3,6 & 1,69 & 1,28 \\
\hline 11. beteg (T. Cs.) & 63 & Férfi & 2 & 6,06 & 1,79 & 1,45 \\
\hline
\end{tabular}

jelentkezett, melyek általában éjszaka és nyugalomban erősödtek, és mozgatásra enyhültek. A fekély nélküli polyneuropathiás betegcsoportunkban 6 beteg volt. Kutatásaink során olyan betegeket választottunk, ahol gabapentin- vagy pregabalintartalmú gyógyszeres kezelésre a polyneuropathiás tünetek nem kellő mértékben javultak. A Tanszékünkön elvégzett rheopheresiskezelések hatására 1 beteg kivételével minden esetben jelentősen javultak a páciensek panaszai, gyakran már egyetlen kezelés is csökkentette a neuropathiás fájdalmat. A gyógyszeres fájdalomcsillapító-igény szintén csökkent a rheopheresis hatására. A szubjektív javulás - 1 esetet leszámítva - objektíven is alátámasztható volt a kezeléseket követő ENG-vizsgálatokkal, melyek során megnövekedett amplitúdó és javuló vezetési sebességek igazolták a kezelés hatásosságát. I páciens esetében javultak a motoros rostok amplitúdói, mintegy 36\%-kal, és 3 páciensnél volt kimutatható a szenzoros rostok javulása - ezekben az esetekben a vezetési amplitúdó átlagosan 2,2 $\mu \mathrm{V}$-tal nö- vekedett. 1 esetben növekedett a szenzoros rostok vezetési sebessége, mintegy 17,3 m/s-mal, ez 48,3\%-os növekedést jelentett. 1 esetben a páciens panaszai szubjektíven javultak, ám az ENG ezeket nem támasztotta alá, 1 esetben pedig sem a panaszok változása, sem az ENG-vizsgálat nem igazolta a kezelés sikerességét. A diabeteses neuropathia kezeléséről szóló részletes eredményeinket a 3. és a 4. táblázat mutatja be.

A 12, fekélyes beteg közül 4-nél fennállt a polyneuropathia diagnózisa is. A korábban gyógyhajlamot nem mutató fekélyek átlagosan 2 kezelést követően kezdtek jelentős mértékben javulni, illetve szanálódni. l esetben a kezeléseket követően nem történt érdemi változás, míg 2 esetben a páciens alsó végtagjának részleges amputációja elkerülhetetlen volt - kiemelendő azonban, hogy ezekben az esetekben a betegek rendkívül rosszul múködtek együtt, ami nagyban nehezítette a kezelést. 9 páciensnél részleges vagy teljes gyógyulást értünk el a diabetes talaján kialakult fekélyek rheopheresiskezelésével. 
4. táblázat | Diabeteses neuropathiában szenvedő páciensek tüneteinek és az ENG-vizsgálatnak a változása a rheopheresis után

A panaszok és az ENG változása a kezelések után

6. beteg (G. M.) Csökkent fájdalomcsillapító-igény, az alvás minőségének javulása

Mko. nervus peroneus motoros rostjaiban amplitúdónöpekedés

A bal oldali nervus peroneus motoros amplitúdói kezelés $\quad$ A jobb oldali nervus peroneus motoros amplitúdói kezelés előtt és után: előtt és után:

\begin{tabular}{ll|ll}
\hline Boka-EDB: 1,64 mV Boka-EDB: $2,1 \mathrm{mV}$ & Boka-EDB: 1,24 mV Boka-EDB: $1,79 \mathrm{mV}$ \\
\hline
\end{tabular}

7. beteg (E. J.) A Aájdalom mérséklődése

A jobb nervus peroneus superficialis szenzoros vezetésének javulása

A jobb nervus peroneus superficialis szenzoros vezetése kezelés előtt és után:

\begin{tabular}{l|l}
\hline Calf - Ankle lat.: $35,8 \mathrm{~m} / \mathrm{s}$ & Calf - Ankle lat.: $53,1 \mathrm{~m} / \mathrm{s}$ \\
\hline
\end{tabular}

Mko. nervus suralis szenzoros rostjaiban amplitúdónöpekedés

A bal oldali nervus suralis szenzoros amplitúdói kezelés $\quad$ A jobb oldali nervus suralis szenzoros amplitúdói kezelés előtt és után: előtt és után:

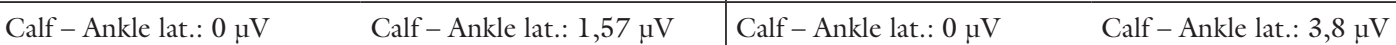

8. beteg (Cs. Z.) A zsibbadás mérséklődése

Mko. nervus peroneus superficialis szenzoros rostjaiban amplitúdónövekedés

\begin{tabular}{l|l}
\hline A bal oldali nervus peroneus superficialis szenzoros & A jobb oldali nervus peroneus superficialis szenzoros
\end{tabular} amplitúdói kezelés előtt és után:

Tib. lat. - Ankle: $0,62 \mu \mathrm{V} \quad$ Tib. lat. - Ankle: $3.8 \mu \mathrm{V}$ amplitúdói kezelés előtt és után:

Mko. nervus suralis szenzoros rostjaiban amplitúdónövekedés

A bal oldali nervus suralis szenzoros amplitúdói kezelés $\quad$ A jobb oldali nervus suralis szenzoros amplitúdói kezelés előtt és után: előtt és után:

\begin{tabular}{ll|l} 
Calf - Ankle lat.: $3,7 \mu \mathrm{V} \quad$ Calf - Ankle lat.: $4,3 \mu \mathrm{V}$ & Calf - Ankle lat.: $4,0 \mu \mathrm{V} \quad$ Calf - Ankle lat.: $7,1 \mu \mathrm{V}$
\end{tabular}

9. beteg (M. I.) Panaszai nem változtak

Az ENG nem mutatott változást

10. beteg (Cs. L.) Az állandó fájdalom mérséklődött, az 'égô' panaszok csökkentek

A korábban diagnosztizált polyneuropathia motoros mononeuropathiára redukálódott

11. beteg (T. Cs.) Alsó végtagi zsibbadása megszűnt, obstipatiós panaszai rendeződtek

Az ENG nem mutatott változást

$\mathrm{EDB}=$ extensor digitorum brevis; $\mathrm{ENG}=$ elektroneurográfia $;$ Mko. $=$ mindkét oldali

K. K. betegünk talpi fekélyének mérete a kezeléseket megelőzően $6 \times 6 \mathrm{~cm}$ méretű volt, 1 cm-es sebmélységgel, mely gyógyulási hajlamot nem mutatott. A kezeléseket követően a fekély gyógyulni kezdett, a rheopheresisek után 5 hónappal a fekély 1,4 × 1,7 cm méretüre zsugorodott, 0,5 cm mélységgel. A gyógyulás folyamatát az 1 ábrán láthatjuk.

Az ulcusos betegek kezelésre adott válaszát a haemorrheologiai paraméterek változásával, illetve a kezelések számával együtt az 5. és a 6. táblázatban foglaljuk össze.

\section{Egyéb, hiperviszkozitással együtt járó vasculopathiák - a rheopheresiskezeléssel szerzett tapasztalataink}

A rheopheresiskezelést alkalmaztuk 2 további beteg esetében is. Az egyik betegünk (F. Cs.) súlyos perifériás artériás érbeteg volt, akinél a cruralis kiáramlás hiánya miatt revascularisatióra nem volt lehetőség. Tekintettel a súlyos dysbasiás tünetekre, rheopheresiskezelést végeztünk, amellyel az igazoltan magas hiperviszkozitását rendeztük: teljesvér-viszkozitása 4,97-ről 4,33 mPas-ra (90 $\mathrm{s}^{-1}$ sebességgradiensnél), míg plazmaviszkozitása 2,2-ról 1,53 mPas-ra csökkent. Claudicatiós panaszai is javultak; dysbasiás távolsága 100 méterről 150-re emelkedett, trophicus fekélye nem jelentkezett.

A másik beteg (Sz. I.) 50 éves, antifoszfolipid-szindrómában szenvedő nőbeteg; klinikai manifesztációja alsó végtagi perifériás atherothrombosis volt, mely súlyos necrosisig fokozódó ischaemiás keringészavart okozott. Tekintettel a súlyos klinikai állapotra, szelektív apheresist végeztünk, majd nagy dózisú intravénás immunglobulin-kezelést alkalmaztunk az antitesttiter gyors csökkentésének céljából. A komplex kezelés ellenére állapota csak nagyon lassan javult, ezért rheopheresiskezeléssel egészítettük ki terápiáját a mikrocirkuláció javítására. A több támadáspontú kezelés hatására az ischaemiás folyamat megállt, a necrosis demarkálódott, később autoamputációval gyógyult. 


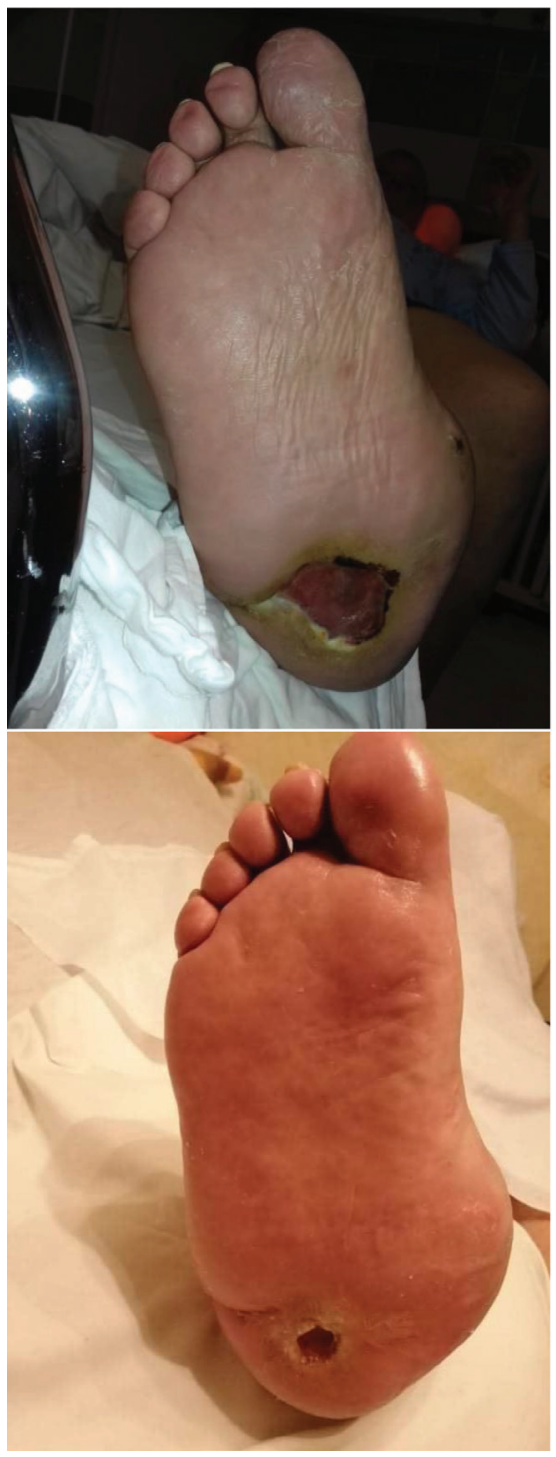

1. ábra

K. K. betegünk fekélyének gyógyulási folyamata a rheopheresis hatására \begin{tabular}{l|l} 
6. táblázat & $\begin{array}{l}\text { Diabeteses alsó végtagi fekélyben szenvedő betegek tünetei a } \\
\text { rheopheresis előtt és után }\end{array}$
\end{tabular}

A panaszok változása a kezelés előtt (E) és után $(\mathrm{U})$

12. beteg (L. I.) E: A jobb I-II-III. lábujj amputációját követő
hegben gennyes fekélyek

U: Gyógyult fekélyek

13. beteg (B. J.) E: A bal I. lábujj fekélye

U: Gyógyult fekély

14. beteg (K. B) E: Jobb oldali lábszárfekély

U: Gyógyult fekély

15. beteg (N. I.) E: A bal I-II-III. lábujj fekélye

U: Gyógyult fekély; U: az I-II. lábujj fekélye gyógyult, a III. lábujj demarkálódott

16. beteg (Sz. F.) E: A bal IV-V. lábujjon necroticus sebek U: Amputáció

17. beteg (T. M.) E: Bal talpi fekély U: Gyógyhajlamot mutató fekély

18. beteg (T. T.) E: A jobb I. lábujj fekélye U: Gyógyhajlamot mutató fekély

19. beteg (F. É.) E: Mindkét sarkán megjelenő neuropathiás fekély

$\mathrm{U}$ : Javult mikro- és makrocirkuláció

20. beteg (P. I.) E: A jobb belboka feletti, gyógyhajlamot nem mutató fekély

U: Gyógyult fekély

21. beteg (P. J.) E: Bal oldali, gyógyhajlamot nem mutató lábszárfekély

U: Gyógyult fekély

22. beteg (K. K.) E: Jobb talpi, gyógyhajlamot nem mutató fekély U: Gyógyult fekély

23. beteg (S. J.) E: Bal oldali, gyógyhajlamot nem mutató lábszárfekély

U: Gyógyult fekély

$\mathrm{E}=$ a kezelés előtt; $\mathrm{U}=$ a kezelés után

5. táblázat | Diabeteses alsó végtagi fekélyben szenvedő betegek teljesvér- és plazmaviszkozitásának változása a rheopheresis hatására

\begin{tabular}{|c|c|c|c|c|c|c|c|}
\hline \multirow[b]{2}{*}{ 12. beteg (L. I.) } & \multirow{2}{*}{$\begin{array}{l}\text { Kor } \\
43 \\
43\end{array}$} & \multirow{2}{*}{$\begin{array}{l}\text { Nem } \\
\text { Férfi }\end{array}$} & \multirow{2}{*}{$\begin{array}{l}\text { A rheopheresisek } \\
\text { száma }\end{array}$} & \multicolumn{2}{|c|}{$\begin{array}{c}\text { Teljesvér-viszkozitás } \\
\left(90 \mathrm{~s}^{-1} \text { sebességgradiensnél) }\right. \\
\text { kezelés előtt és után [mPas] }\end{array}$} & \multicolumn{2}{|c|}{$\begin{array}{l}\text { Plazmaviszkozitás kezelés előtt és után } \\
\qquad[\mathrm{mPas}]\end{array}$} \\
\hline & & & & 5,43 & 4,26 & 1,43 & 1,17 \\
\hline 13. beteg (B. J.) & 59 & Férfi & 4 & 6 & 4,04 & 4,23 & 1,24 \\
\hline 14. beteg (K. B.) & 73 & Nő & 2 & 5.95 & 4,68 & 1,94 & 1,51 \\
\hline 15. beteg (N. I.) & 67 & Férfi & 1 & 4,15 & 4,0 & 1,55 & 1,51 \\
\hline 16. beteg (Sz. F.) & 64 & Férfi & 2 & Mérhetetlen & 4,34 & Mérhetetlen & 1,54 \\
\hline 17. beteg (T. M) & 52 & Férfi & 2 & 4,85 & 4,49 & 1,5 & 1,49 \\
\hline 18. beteg (T. T.) & 65 & Férfi & 2 & 5,27 & 3,63 & 1,54 & 1,37 \\
\hline 19. beteg (F. É.) & 62 & Nő & 2 & 6,63 & 3,29 & 1,7 & 1,45 \\
\hline 20. beteg (P. I.) & 66 & Férfi & 3 & 4,9 & 3,31 & 1,57 & 1,19 \\
\hline 21. beteg (P. J.) & 68 & Férfi & 4 & 7 & 4,52 & 1,44 & 1,17 \\
\hline 22. beteg (K. K.) & 56 & Férfi & 2 & 5,07 & 4,62 & 1,45 & 1,4 \\
\hline 23. beteg (S. J.) & 75 & Nő & 2 & 5,98 & Kontroll 2020-ban & 1,94 & Kontroll 2020-ban \\
\hline
\end{tabular}




\section{Megbeszélés}

Az apheresiseljárások technológiai fejlődése lehetővé tette, hogy a kezelések egyre szelektívebbé váljanak, ezáltal egyre szélesítve a sikeresen kezelhetó kórképek palettáját [14]. Korábban az Orvosi Hetilap hasábjain számoltunk be az első magyarországi immunadszorpciós kezelésről dilatatív cardiomyopathiában [15]. Jelen munkákban a rheopheresiskezelés helyét kerestük hiperviszkozitással összefüggő, mikrocirkulációs zavarral együtt járó megbetegedések terápiájában. A rheopheresis - mint szelektív terápiás apheresiseljárás - a vérplazma viszkozitását fokozó, 250-300 kDa mérettartománynál nagyobb méretú makromolekulák szeparációjával képes a beteg haemorrheologiai statusát javítani. A kezelésnek köszönhetően csökken a vérplazmában az LDL, a lipoprotein(a), a fibrinogén, az $\alpha 2$-makroglobulin, a VWF, illetve az IgM-típusú immunglobulinok mennyisége, továbbá a thrombocytaaktivitást jelző P-szelektin szintje is. Ezen pozitív hatásoknak köszönhetően a kezelés jelentősen javítja a vér viszkozitását, javítja a szövetek mikrocirculációját, növeli oxigénellátottságukat, ugyanakkor csökkenti a thrombocytaaggregációt, antithrombogen és endothelstabilizáló hatással bír [1]. Korábbi kutatásunkban egy igazolt AMD-s páciens esetében vizsgáltuk, hogy a haemorrheologiai paraméterek rendezésén túl egyéb pozitív hatás is jelentkezik-e a kezelés eredményeként. A kezelések alatt elvégzett vizsgálataink azt mutatták, hogy a rheopheresiskezelés hatására a viszkozitási értékek javulásán túl további jótékony hatások is detektálhatók. A gyulladást jelző monocytaaktivitást csökkentő, a prooxidáns status javulását jelző phagocytakemilumineszcenciát normalizáló, az antithromboticus folyamatot jelző P-szelektin-expressziót csökkentő hatásáról számoltunk be. Ennek eredményeit a Clinical Hemorbeology and Microcirculation lapban publikáltuk [2].

Az American Society for Apheresis legfrissebb ajánlása alapján a rheopheresis bizonyítottan hatásos az olyan, mikrocirkulációs zavarral járó megbetegedésekben, mint az időskori száraz maculadegeneratio, továbbá a sensorineuralis hallásvesztés [4]. Jól ismert tény, hogy a diabeteses láb szindrómájában a microangiopathiás érdestrukció - mely az 500 um-nél kisebb érátmérőjú praecapillaris arteriolákat és capillarisokat érinti - kitüntetett fontossággal bír [16]. Tekintve, hogy Magyarországon átlagosan évi 5000 lábamputációt végeznek - amelyek döntő hányadát előzi meg diabetes következtében kialakuló neuroischaemiás fekély -, a kórkép kezelésére kiemelten nagy hangsúlyt kell fektetni [17].

A rheopheresisterápiát 2014-ben vezettük be intézetünkben, s az elmúlt 5 évben összesen 25 pácienst részesítettünk ebben a kezelésben, mintegy 80 alkalommal.

A rheopheresissel már bizonyítottan kezelhető időskori száraz maculadegeneratio terápiája mellett a kezelés alkalmazását kutatócsoportunk kiterjesztette a hiperviszkozitással összefüggő mikrocirkulációs zavarral járó an- giológiai kórképekre, úgymint diabeteses alsó végtagi fekély és neuropathia. Mindkét kórkép esetében jelentős sikereket értünk el. Az időskori száraz maculadegeneratio esetében 5 páciensnél alkalmaztunk összesen 25 rheopheresist. Minden beteg panasza nagymértékben csökkent, rendkívül gyorsan. Látóélességük, ezáltal életminőségük jelentősen javult, e pozitív hatásokat pedig az OCT-vizsgálatok is alátámasztották. Ez azért is jelentős, mert a száraz AMD esetében hatásos gyógymód nem ismert.

A diabeteses láb szindrómája egy rendkívül komplex folyamat következménye - ebből fakadóan igen nehezen kezelhető állapot, s ezáltal népegészségügyi jelentősége óriási [12]. Azoknál a pácienseknél, akiknek az érstatusa nem alkalmas vascularis rekonstrukcióra, és esetlegesen súlyos, terápiára nem megfelelően reagáló neuropathiás panaszokkal bírnak, a mikrocirkuláció javítása kulcsfontosságú jelentôséggel bír [16]. Azon pácienseket, akiknek mindemellett a teljesvér- és/vagy plazmaviszkozitásuk a fiziológiásnál magasabb értéket mutatott, rheopheresiskezelésben részesítettük. Mindeddig 18, diabetesesláb-szindrómában szenvedő beteget kezeltünk, 53 alkalommal. Ezen kezelések eredményeként a fekélyek sebgyógyulása felgyorsult azon esetekben, amikor az ulcusok gyógyhajlamot nem mutattak, szanálódni kezdtek. További pozitív hatások leírhatók a neuropathiával kapcsolatban. Elmondható, hogy a rheopheresiskezeléssel a páciensek neuropathiás fájdalma csökkenthető, amit az elvégzett ENG-vizsgálatok pozitív irányú változásai igazolnak. A diabeteses láb terápiájában elért eredményeink túlmutatnak a haemorrheologián, kutatásaink folynak az itt megfigyelhető antioxidáns és antiinflammatorikus hatásokkal kapcsolatban.

Anyagi támogatás: A közlemény megírása, illetve a kapcsolódó kutatómunka anyagi támogatásban nem részesült.

Szerzői munkamegosztás: S. P.: A kézirat megszövegezése, a vizsgálat lefolytatása. M. L.: Szemészeti vizsgálatok végzése. G. K., V. M., D. Á.: A rheopheresiskezelésekben való részvétel. ${ }^{\dagger}$ M. F., F. K.: ENG-vizsgálatok végzése. S. V., N. N.: Viszkozitásvizsgálatok végzése. A cikk végleges változatát valamennyi szerző elolvasta és jóváhagyta.

Érdekeltségek: A szerzőknek nincsenek érdekeltségeik.

\section{Köszönetnyilvánítás}

A szerzők köszönetet mondanak a Fresenius Medical Care Magyarország Egészségügyi Kft.-nek, akik a rheopheresiskezelés bevezetéséhez szükséges technikai hátteret biztosították. Köszönet illeti Bozóki-Beke Krisztina és Fábiánné Gelsi Eleonóra intenzív osztályos szakasszisztenseket a kezelésekben nyújtott tevékenységükért. Köszönet illeti továbbá Baráth Barbarát és Varga Ádámot (Sebészeti Mútéttani Tanszék) a haemorrheologiai mérésekben nyújtott segítségükért. 


\section{Irodalom}

[1] Diószegi Á, Vass M, Németh N, et al. Rheopheresis treatment of diabetic foot syndrome. Atherosclerosis 2017; 263: E272.

[2] Vass M, Diószegi Á, Németh N, et al. Rheopheresis in vascular diseases. Clin Hemorheol Microcirc. 2016; 64: 977-987.

[3] Klingel R, Mumme C, Fassbender M, et al. Rheopheresis in patients with ischemic diabetic foot syndrome: results of an open label prospective pilot trial. Ther Apher Dial. 2003; 7: 444-455.

[4] Padmanabhan A, Conelly-Smith L, Aqui N, et al. Guidelines on the use of therapeutic apheresis in clinical practice - evidencebased approach from the Writing Committee of the American Society for Apheresis: the eighth special issue. J Clin Apher. 2019; 34: 171-354.

[5] Pennington KL, DeAngelis MM. Epidemiology of age-related macular degeneration (AMD): associations with cardiovascular disease phenotypes and lipid factors. Eye Vis (Lond). 2016; 3: 34.

[6] Jager RD, Mieler WF, Miller JW. Age-related macular degeneration. N Engl J Med. 2008; 358: 2606-2617. [Erratum: N Engl J Med. 2008; 359: 1736.]

[7] Heesterbeek TJ, Lorés-Motta L, Hoyng C, et al. Risk factors for progression of age-related macular degeneration. Ophthalmic Physiol Opt. 2020; 40: 140-170.

[8] Lipécz A., Miller L, Kovács I, et al. Microvascular contributions to age-related macular degeneration (AMD): from mechanisms of choriocapillaris aging to novel interventions. GeroScience 2019; 41: 813-845.

[9] Klingel R, Fassbender C, Fischer I, et al. Rheopheresis for agerelated macular degeneration: a novel indication for therapeutic apheresis in ophthalmology. Ther Apher. 2002; 6: 271-281.
[10] Alexiadou K, Doupis J. Management of diabetic foot ulcers. Dia betes Ther. 2012; 3 : 4 .

[11] Beggs J, Johnson PC, Olafsen A, et al. Innervation of the vasa nervorum: changes in human diabetics. J Neuropathol Exp Neurol. 1992; 51: 612-629.

[12] Noor S, Khan RU, Ahmad J. Understanding diabetic foot infection and its management. Diabetes Metab Syndr. 2017; 11: 149-156.

[13] Mátrai A, Whittington RB, Ernst E. A simple method of estimating whole blood viscosity at standardized hematocrit. Clin Hemorh Microcirc. 1987; 7: 261-265.

[14] Soltész P. National survey of the therapeutic apheresis in Hungary, 2013-2017. [A terápiás apheresisek számának és indikációjának változása, valamint új eljárások megjelenése Magyarországon 2013 és 2017 között.] Orv Hetil. 2019; 160: 727-738. [Hungarian]

[15] Soltész P, Vass M, Diószegi Á, et al. Immunoadsorption in dilatative cardiomyopathia. The first case in Hungary. [Dilatatív cardiomyopathia immunadszorpciós kezelése. Az első magyarországi eset kapcsán.] Orv Hetil. 2018; 159: 526-530. [Hungarian]

[16] Dinh T, Veves A. Microcirculation of the diabetic foot. Curr Pharm Des. 2005; 11: 2301-2309.

[17] Kolossváry E, Ferenci T, Kováts T, et al. Trends in major lower limb amputations related to peripheral arterial disease in Hungary: a nationwide study (2004-2012). Eur J Vasc Endovasc Surg. 2015 ; 50: 78-85.

(Soltész Pál dr., Debrecen, Móricz Zs. krt. 22., 4032 e-mail: dr.soltesz.pal@gmail.com)

\section{"Pericla qui audet ante vincit quam accipit." (A merész legyőzi a veszélyt, még mielőtt az rátalál.)}

A cikk a Creative Commons Attribution 4.0 International License (https://creativecommons.org/licenses/by/4.0/) feltételei szerint publikált Open Access közlemény, melynek szellemében a cikk bármilyen médiumban szabadon felhasználható, megosztható és újraközölhető, feltéve, hogy az eredeti szerző és a közlés helye, illetve a CC License linkje és az esetlegesen végrehajtott módositások feltüntetésre kerülnek. (SID_1) 